\title{
Corrigenda
}

Genome Research 29: 2088-2103 (2019)

\section{Corrigendum: Murine single-cell RNA-seq reveals cell-identity- and tissue-specific trajectories} of aging

Jacob C. Kimmel, Lolita Penland, Nimrod D. Rubinstein, David G. Hendrickson, David R. Kelley, and Adam Z. Rosenthal

The authors would like to correct an error in the Methods section of the above-mentioned article under the "Quality control" subheading. The corrected text is as follows and has been updated in the article online:

"Additionally, we filtered out cells with a high fraction of reads mapping to the mitochondrial genome (>10\%) or the $R n 45 s$ repeat (>5\%) as likely dead cells (Ilicic et al. 2016)."

The authors apologize for any confusion this may have caused.

doi: $10.1101 /$ gr.259820.119

Genome Research 29: 506-519 (2019)

Corrigendum: Dynamics of cardiomyocyte transcriptome and chromatin landscape demarcates key events of heart development

Michal Pawlak, Katarzyna Z. Kedzierska, Maciej Migdal, Karim Abu Nahia, Jordan A. Ramilowski, Lukasz Bugajski, Kosuke Hashimoto, Aleksandra Marconi, Katarzyna Piwocka, Piero Carninci, and Cecilia L. Winata

The authors would like to correct an omission in the Methods section of the above-mentioned article under the "CM collection by fluorescence-activated cell sorting (FACS)" subheading. The corrected text is as follows and has been updated in the article online:

"Cell suspension was prepared from 500 embryos and larvae as previously described (Winata et al. 2013), omitting the fixation step and directly resuspending cells in FACSmax Cell Dissociation Solution (AMS Biotechnology) for cell sorting."

The authors apologize for any confusion this may have caused.

doi: $10.1101 /$ gr.260273.119 


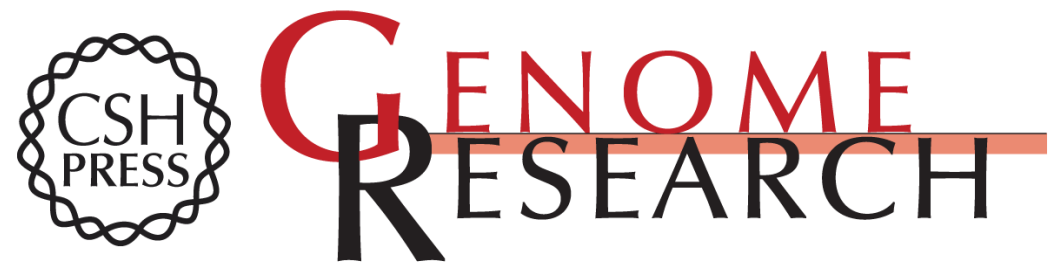

\section{Corrigendum: Dynamics of cardiomyocyte transcriptome and chromatin landscape demarcates key events of heart development}

Michal Pawlak, Katarzyna Z. Kedzierska, Maciej Migdal, et al.

Genome Res. 2020 30: 153_2

Access the most recent version at doi:10.1101/gr.260273.119

Related Content Dynamics of cardiomyocyte transcriptome and chromatin landscape demarcates key events of heart development

Michal Pawlak, Katarzyna Z. Kedzierska, Maciej Migdal, et al.

Genome Res. March , 2019 29: 506-519

Open Access Freely available online through the Genome Research Open Access option.

License

Email Alerting Receive free email alerts when new articles cite this article - sign up in the box at the Service top right corner of the article or click here.

\section{Affordable, Accurate Sequencing.}

To subscribe to Genome Research go to:

https://genome.cshlp.org/subscriptions 